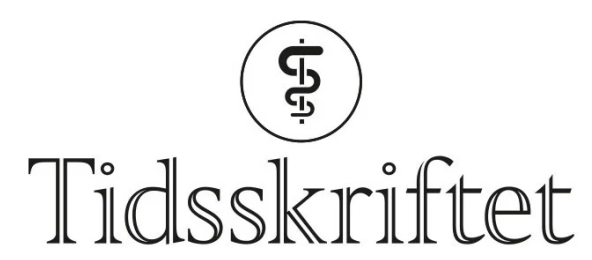

DEN NORSKE LEGEFORENING

\title{
Et konsentrert blikk på radiologi
}

ANMELDELSER

ANNE SOFIE FRØYSHOV LARSEN

Sykehuset $\emptyset$ stfold

Radiologisk avdeling

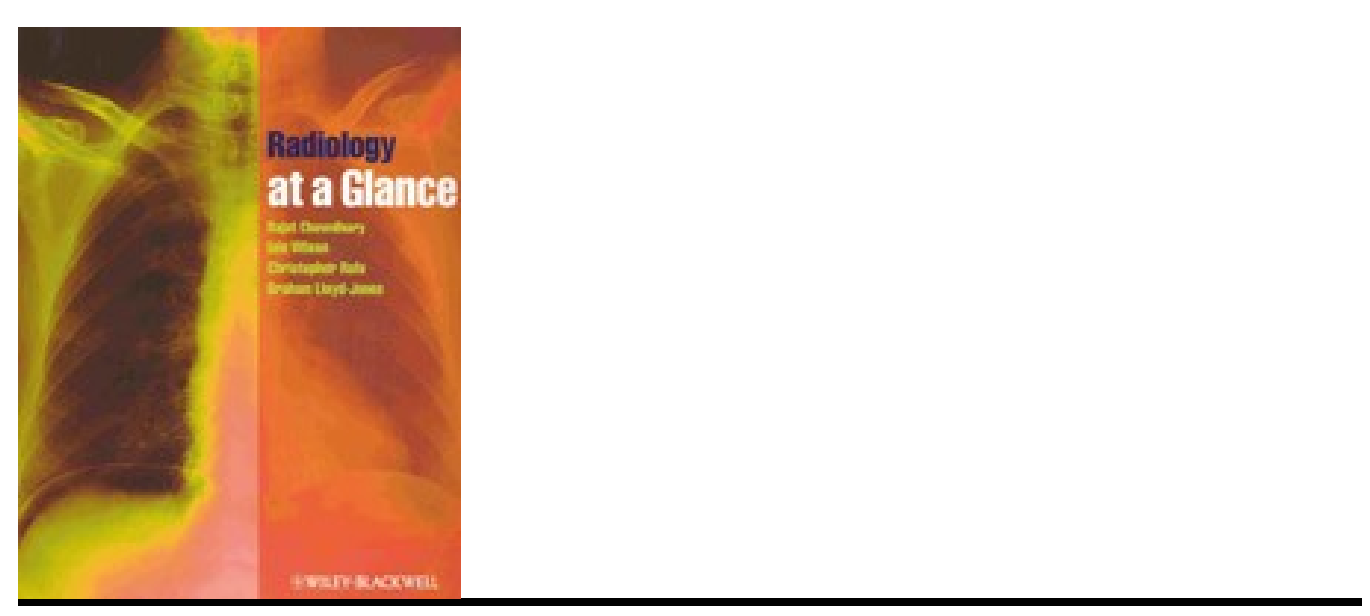

Chowdhury, Rajat

Wilson, Iain

Rofe, Christopher

Radiology at a glance

120 s, ill. Chichester: Wiley-Blackwell, 2010. Pris GBP 22

ISBN 978-1-4051-9220-0

Denne slanke boken inngår i en serie «at a glance», som omhandler i alt 32 ulike medisinske emner. Målgruppen er medisinstudenter og ferske leger, men den kan også være nyttig for studenter innen radiografi, sykepleie, fysioterapi og annet helsepersonell. Teksten er bygd opp omkring typiske funn ved ulike kliniske tilstander, etter en kort introduksjon til de ulike modalitetene, fysikk, bruk av kontrastmidler og strålehygiene. I hvert kapittel er det inkludert en seksjon om radiologisk anatomi innen den aktuelle modaliteten. Det er rikelig med gode illustrasjoner, og hvert tema eller kasuistikk er avsluttet på en 
dobbeltside. Alle hovedtemaene innen radiologi er dekket, med ulik vekting. Hovedvekten ligger på vanlig røntgen, men også CT og MR er omtalt i litt større kapitler. Ultralyd, gjennomlysning, intervensjonsradiologi og nukleærmedisin er kun meget kort beskrevet.

Boken er tilpasset problembasert studieteknikk, og forfatterne angir at et av målene er å gi kunnskap som kan føre til riktig henvisningspraksis og forståelse av nytten av bildediagnostikk i klinisk praksis.

I Norge er og har det vært behov for at leger selvstendig skal kunne tolke konvensjonelle røntgenbilder både i sykehus og i legevaktsammenheng. Radiology at a glance gir en grei innføring i dette, men er ikke uttømmende. I tillegg er ultralyd en modalitet som brukes i stadig flere kliniske spesialiteter, herunder allmennmedisin, og kapitlet om ultralyd er således skuffende kort.

Siden denne er laget med tanke på utdanningen i Storbritannia, refererer den til regelverket der, både når det gjelder strålehygiene og henvisning til bildediagnostikk. Også de eksamensrettede sluttkapitlene er preget av dette. The Royal College of Radiology har utarbeidet retningslinjer for bruk av bildediagnostikk (2007), og disse refereres. Både regelverk og retningslinjer harmonerer imidlertid godt med norsk praksis, og overføringsverdien er derfor stor.

Den konsentrerte formen gjør at mye informasjon formidles til leseren på lite plass, noe som kan være en utfordring i en læresituasjon. Forenkling gir også av og til unøyaktigheter. Men alt i alt er dette en god innføring i radiologi og velegnet for målgruppen. Boken er også godt oppdatert innen et fag i rivende utvikling.

Publisert: 18. november 2010. Tidsskr Nor Legeforen. DOI: 10.4045/tidsskr.10.1045

(C) Tidsskrift for Den norske legeforening 2023. Lastet ned fra tidsskriftet.no 26. april 2023. 